\title{
AZ ÁLLAMI EGÉSZSÉGÜGYI TARTALÉK HELYZETE NAPJAINKBAN
}

\section{THE ACTUAL STATUS OF THE PUBLIC EMERGENCY HEALTHCARE SUPPLY}

\author{
HALÁCHY Enikő \\ (ORCID: 0000-0001-7528-4990) \\ halachy.eniko@gmail.com
}

\begin{abstract}
Absztrakt
A biztonság átfogó megközelítése, a veszélyhelyzetek és válsághelyzetek kezelése és felszámolása kapcsán felmerülö katonai-, katasztrófavédelmi- és civil együttmüködés meghatározó eleme az Állami Egészségügyi Tartalék. Az ismertetésen túl, a cikk az Állami Egészségügyi Tartalék elhelyezkedését vizsgálja a védelmi célú tartalékok, és a katasztrófák elleni védekezés rendszerében.
\end{abstract}

Kulcsszavak: Állami Egészségügyi Tartalék, védelmi célú tartalék, biztonság, egészégügyi válsághelyzet, szükséggyógyintézet

\begin{abstract}
Public Emergency Healthcare Supply is a key element of the military, disaster response and civil cooperation in a comprehensive approach to security, emergency and crises management. Besides description of the subject, the article examines the location of the Public Emergency Healthcare Supply in the system of defence reserves and disaster management.
\end{abstract}

Keywords: Public Emergency Healthcare Supply, defence reserve, safety, health disaster, mobile hospital 


\section{BEVEZETÉS}

A természeti jelenségek okozta katasztrófaveszély, továbbá civilizációs veszélyek (pl: migráció, fegyveres- és bioterrorizmus, járványok, stb.) fokozódása miatt egyre nagyobb az olyan események bekövetkezésének kockázata, amelyek kezeléséhez szükségessé válhat a különleges jogrend kihirdetése.

Az egészségügyröl szóló 1997. évi CLIV. törvény értelmében különleges jogrend kihirdetése esetén az egészségügyi válsághelyzeti ellátásra vonatkozó rendelkezéseket kell alkalmazni az egész ország területén. [1]

Az egészségügyi válsághelyzeti ellátás biztosítása és finanszírozása állami feladat, mely magába foglalja az erre történő felkészülési tevékenység, valamint a tényleges müködés megszervezését és lebonyolítását is. Az egészségügyi válsághelyzeti ellátásra való felkészülési tevékenység kiterjed az egészségügyi készletek tartalékolására is.

A fenti törvény kimondja azt is, hogy ,,az egészségügyi válsághelyzeti ellátáshoz szükséges, az egészségügyi szolgáltatók, valamint az együttmüködő szervezetek készleteit meghaladó eszközöket és anyagokat az Állami Egészségügyi Tartalékból kell biztosítani.” [1]

Az elmondottakat megerősíti továbbá az egészségügyi válsághelyzeti ellátásról szóló 521/2013. (XII. 30.) Korm. rendelet a 10. §-a, mely szerint ,az állam egészségügyi válsághelyzet esetére a tömeges ellátás feltételeinek biztosítása, a szükséggyógyintézetek müködéséhez, továbbá az egészségügyi válsághelyzeti ellátáshoz szükséges gyógyszerek, egészségügyi anyagok és eszközök azonnali rendelkezésre állása céljából” Állami Egészségügyi Tartalékot tart fenn, és ezt az egészségügyért felelös miniszter felügyeli. [2]

Fentiek alapján nyilvánvaló, hogy a globalizáció felgyorsulásával, a katasztrófák elleni védekezésben várhatóan egyre inkább szerepet kap az Állami Egészségügyi Tartalék is. Ezért is fontos áttekinteni az Állami Egészségügyi Tartalék jelenlegi helyzetét, struktúráját, a készletezésével kapcsolatos általános kérdéseket.

\section{AZ ÁLLAMI EGÉSZSÉGÜGYI TARTALÉK ÁLTALÁNOS BEMUTATÁSA}

Magyarországon az Állami Egészségügyi Tartalék készletezésével az 1960-as években kezdtek foglalkozni, akkor az egészségügyért felelős minisztérium szervezeti egysége látta el a feladatot. 1970-es évtől kezdődően az Állami Egészségügyi Tartalék kezelése a szaktárca háttérintézményeként, önálló gazdálkodás keretében müködött tovább, majd 2017-től napjainkig a korábban önállóan müködő intézet az Állami Egészségügyi Ellátó Központ Egészségügyi Készletgazdálkodási Főosztályaként beintegrálódva végzi a feladatot.

Az Állami Egészségügyi Tartalék készletezése az Állami Egészségügyi Tartalékkal való gazdálkodás szabályairól szóló 1/2016. (I. 13.) EMMI rendelet szerint történik. [3]

Az Állami Egészségügyi Tartalék a Kormány által meghatározott rendeltetésü és mértékü, az egészségügyi ellátórendszer kapacitásának bővítéséhez, valamint az egészségügyi feladatok ellátásához szükséges tartalékelemeket tartalmazza. [3]

A tartalékelemek raktározása az Állami Egészségügyi Ellátó Központ 38 raktárában, országszerte szétosztva történik. A készletek diszlokációja a hidegháborús doktrínákra vezethető vissza, mikor is tömeghadseregek összecsapására, tömegpusztító fegyveres konfliktusok következményeinek kezelésére, nagyszámú sérültellátásra kellett felkészülni, és ezért a raktárakat potenciális célpontoktól viszonylag távolabbi településeken létesítették.

\section{Az Állami Egészségügyi Tartalék rendeltetése}

A vonatkozó rendelet értelmében az Állami Egészségügyi Tartalék rendeltetése, hogy az egészségügyi válsághelyzetek felszámolása érdekében szükséges kapacitások, az egészségügyi válsághelyzetek következtében keletkező többletigények, az igénytámasztó szervek elvárásai 
HALÁCHY: Az állami egészségügyi tartalék helyzete napjainkban

biztosítva legyenek. Továbbá a fenti jogszabály alapján az egyéb egészségügyi feladatok ${ }^{1}$ ellátásához-, illetve a katasztrófa-elhárításhoz szükséges csapat-egészségügyi többletigényként jelentkezö gyógyszerek, orvostechnikai eszközök, valamint egyéb eszközök és anyagok (a továbbiakban együtt: tartalékelem) mindig rendelkezésre álljanak.

A tartalék rendeltetését az 1. ábra is szemlélteti:

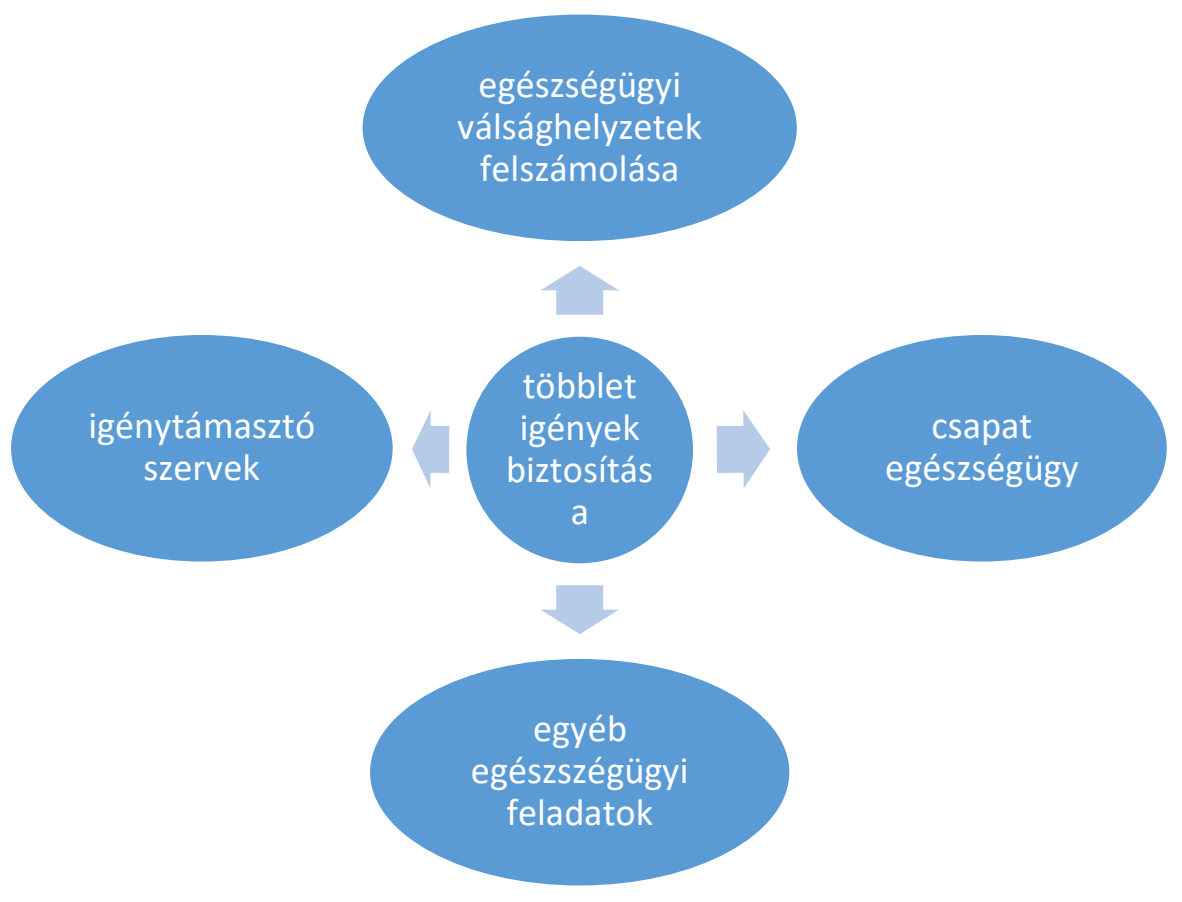

1. ábra. Az Állami Egészségügyi Tartalék rendeltetése (Készítette a szerző, forrás [3])

Az Állami Egészségügyi Tartalék esetében igénytámasztó szervként léphetnek fel a honvédelemért, a rendvédelemért, a katasztrófák elleni védekezésért felelős miniszterek által vezetett minisztériumok, illetve a hivatásos katasztrófavédelmi szerv.

\section{Az Állami Egészségügyi Tartalék összetétele}

Ahogy a 2. ábrán is látható, az Állami Egészségügyi Tartalékot a gyógyszerek, orvostechnikai eszközök, kórháztechnikai berendezések, a különböző fogyóanyagok (kötszerek, egyszerhasználatos eszközök és anyagok, fertőtlenítőszerek), továbbá a szükséggyógyintézetek telepítéséhez szükséges berendezések képezik.

\footnotetext{
${ }^{1}$ Az Állami Egészségügyi Tartalékkal való gazdálkodás szabályiról szóló 1/2016. (I. 13.) EMMI rendelet 6. §-a részletezi
} 


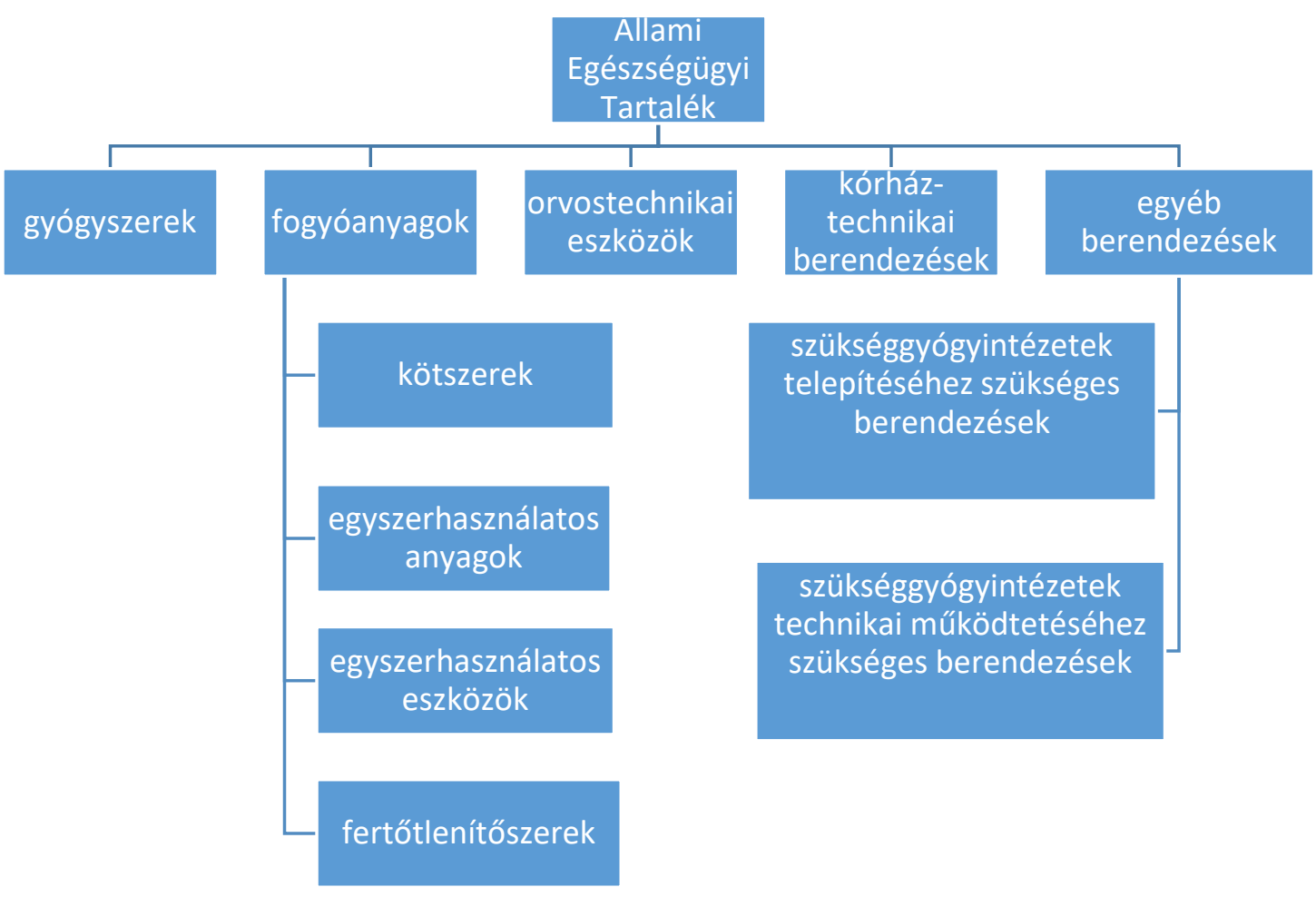

2. ábra Az Állami Egészségügyi Tartalék összetétele (Készítette a szerző, forrás [3])

Az Állami Egészségügyi Tartalék tulajdonképpen a szükséggyógyintézetek felszerelését alkotó normákból, továbbá az igénytámasztó szervek és az egyéb egészségügyi feladatok ellátásához kapcsolódó többletigények kielégítését szolgáló norma feletti és norma részét nem képező készletelemekből áll.

A Tartalék mértékét - az igénytámasztó szervek részére fenntartott készletek esetében annak szükségletei figyelembevételével - az egészségügyért felelős miniszter határozza meg.

A szükséggyógyintézetek tartalmi és mennyiségi összetételét a miniszter által jóváhagyott gyógyszer-, kötszer-, és orvostechnikai eszköz normák határozzák meg.

A normák az Országos Mentőszolgálat, valamint a miniszter által kijelölt fekvőbeteg ellátó intézmények adatszolgáltatása alapján - az Egészségügyi Szakmai Kollégium Oxyológiasürgősségi orvostan, toxikológia, honvéd és katasztrófa orvostan tagozata bevonásával kerülnek kialakításra. [3]

A normákat alkotó készleteket az alábbi funkciók szerinti csoportosíthatjuk:

- gyógyszerek

- $\quad$ kötszerek (tapaszok, kötszerek, égési kötszerek)

- egyszerhasználatos anyagok és eszközök (fecskendők, tük, vizeletgyüjtő zsákok, tubusok, kanülök)

- elektromedikai eszközök (árammal müködő, mérési funkcióval rendelkező diagnosztikai és terápiás eszközök)

- egyéb mérőeszközök (nem árammal müködő, mérési funkcióval rendelkező eszközök)

- mechanikai eszközök (nem elektromos árammal müködő orvostechnikai eszközök, pl. hidraulikus mütőasztalok)

- ápolási eszközök

- betegszállítás és fektetés eszközei

- $\quad$ bútorok (fektetésen kívül eső bútorok, pl. müszerasztal, mütőzsámoly) 
- Röntgen készülékek

- kézimüszerek és müszertálcák

- textíliák és mütéti textíliák

- IVD és laboreszközök

- orvosi gázellátás eszközei (orvosi gázok, gázpalackok, reduktorok)

- fertőtlenítőszerek (eszköz-, bör-, felületfertőtlenítők)

- tisztítás, fertőtlenítés és sterilizálás eszközei (müszermosók, autóklávok, baktericidlámpák)

- sürgősségi és készenléti táskák

- egyéni védőeszközök

\section{A szükség-gyógyintézeti képességek bemutatása}

Ahogy arról a korábbiakban már szó esett, a szükség-gyógyintézetek felszereltségét az orvostechnikai-, kötszer-, és gyógyszernormák határozzák meg.

A jelenlegi szabályozások szerint az alábbi szükség-gyógyintézeti típusok kerültek definiálásra:

\section{Mobil Orvosi Segélyhely (MOSH):}

A Mobil Orvosi Segélyhely a sérültek osztályozására, a tovább szállításra való felkészítésére, az első életmentő szakorvosi ellátásra alkalmas orvosi segélyhely. Füthető-hüthető sátrakban települhet, saját víz- és áramellátással rendelkezik, ezért a kárhelyhez közeli önálló müködésre is alkalmas, így szükség esetén szinte bárhol telepíthető, 2-3 napi müködésre, mintegy 1000 sérült ellátására alkalmas. Mivel ez az Állami Egészségügyi Tartalék leggyorsabban mobilizálható eleme, katasztrófa esetén elsőként kerülhet alkalmazásra, továbbá a Mobil Szükségkórház egyes elemeinek rátelepítésével akár kórházként is tovább müködtethető. Egy mütőblokkal rendelkezik, melyben 2 asztalon egyidejüleg 2 mütéti team dolgozhat. [4;5]

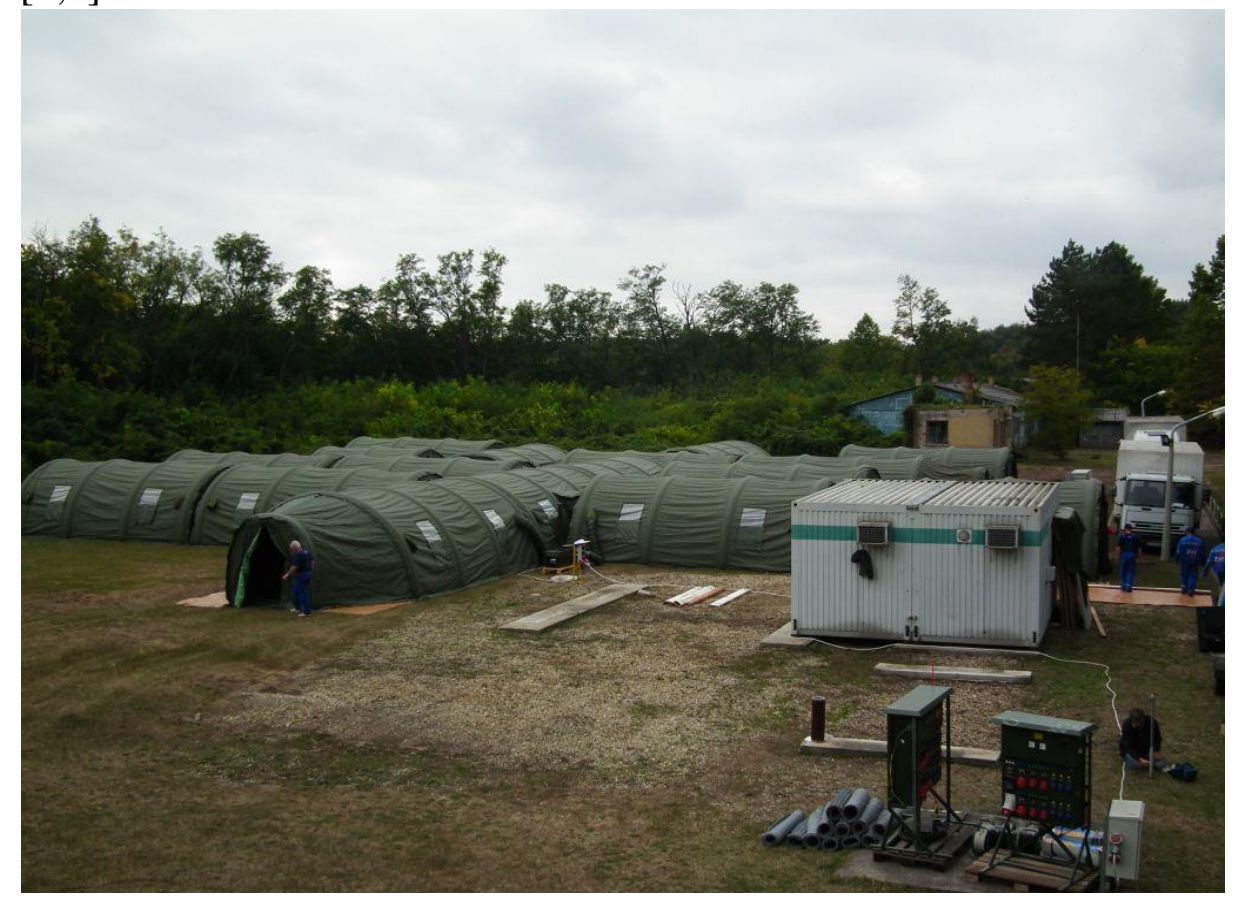

4. ábra Telepített Mobil Orvosi Segélyhely (MOSH)2 (Készítette a szerző, forrás: Magyar Honvédség Kiképző Bázisa, 2014.10.08.)

\footnotetext{
${ }^{2}$ A képen látható komplexum a 2014-ben, katonai-civil együttmüködés keretében megrendezett Mobil Orvosi Segélyhely (MOSH) telepítő és müködtető gyakorlaton készült, a Magyar Honvédség Egészségügyi Központ kiképző bázisán.
} 


\section{Orvosi Segélyhelyek (OH-k):}

A Mobil Orvosi Segélyhelyhez hasonló rendeltetésüek, de annál kevésbé korszerü felszereltséggel rendelkeznek. Feladatuk szintén az osztályozás, az életmentő orvosi beavatkozások elvégzése, másrészt a kórházi ellátást nem igénylő sérültek első ellátása. Az $\mathrm{OH}-$ $\mathrm{k}$ is 2-3 napi működésre, és ez alatt mintegy 800-1000 fö ellátására alkalmasak, de mütőblokkal nem rendelkeznek. [4;5]

\section{Mobil Szükségkórház (MSZK):}

A Mobil Szükségkórház önálló müködésre alkalmas, 400 ágyas, mátrix kórház. Vegyes telepítésü (épület, konténer, sátor), ezért megfelelő szabad környezettel rendelkező épületbe célszerü telepíteni. Két mütöblokkjában 2-2 asztalon egyidejüleg 4 mütéti team dolgozhat. [4;5]

\section{Általános szükségkórház (ÁSZK):}

Az Általános Szükségkórház szintén jól felszerelt 400 ágyas mátrix kórház, de nem teljesen önálló müködésre lett tervezve, ezért elengedhetetlen a telepítő kórházzal való közelség és együttmüködés. Egy mütőblokkal rendelkezik, abban két mütőasztallal, Röntgen képerősítővel. [4;5]

\section{Specifikus Szükségkórház (KSZK):}

A Specifikus Szükségkórház 400 ággyal, elsősorban a telepítő kórház ágyszámának kiegészítésére, a már ellátott, de további kórházi elhelyezést, orvosi felügyeletet és ápolást igénylö betegek elhelyezésére alkalmas. Mütéti blokkal és képalkotó diagnosztikai felszereltséggel nem rendelkezik. [4;5]

\section{Gyorsreagálású Segélycsapat Felszerelés (GYSF):}

Azonnal útba indítható elsősorban a más országok katasztrófa sújtott területeire küldendő magyar segélycsapat részére lett kifejlesztve, de hazai eseménynél is bevethető. Felszerelése egy 10 fös egészségügyi személyzet mintegy egyhetes tevékenységéhez elegendő.

A GYSF által biztosított ellátás szakmai terjedelme a segélycsapat létszáma és szakmai összetétele okán is elsősorban az első életmentő orvosi elsősegélynyújtásra, a kisebb sérülések ellátására, továbbá háziorvosi sürgősségi ellátásra ad lehetőséget. [4;5]

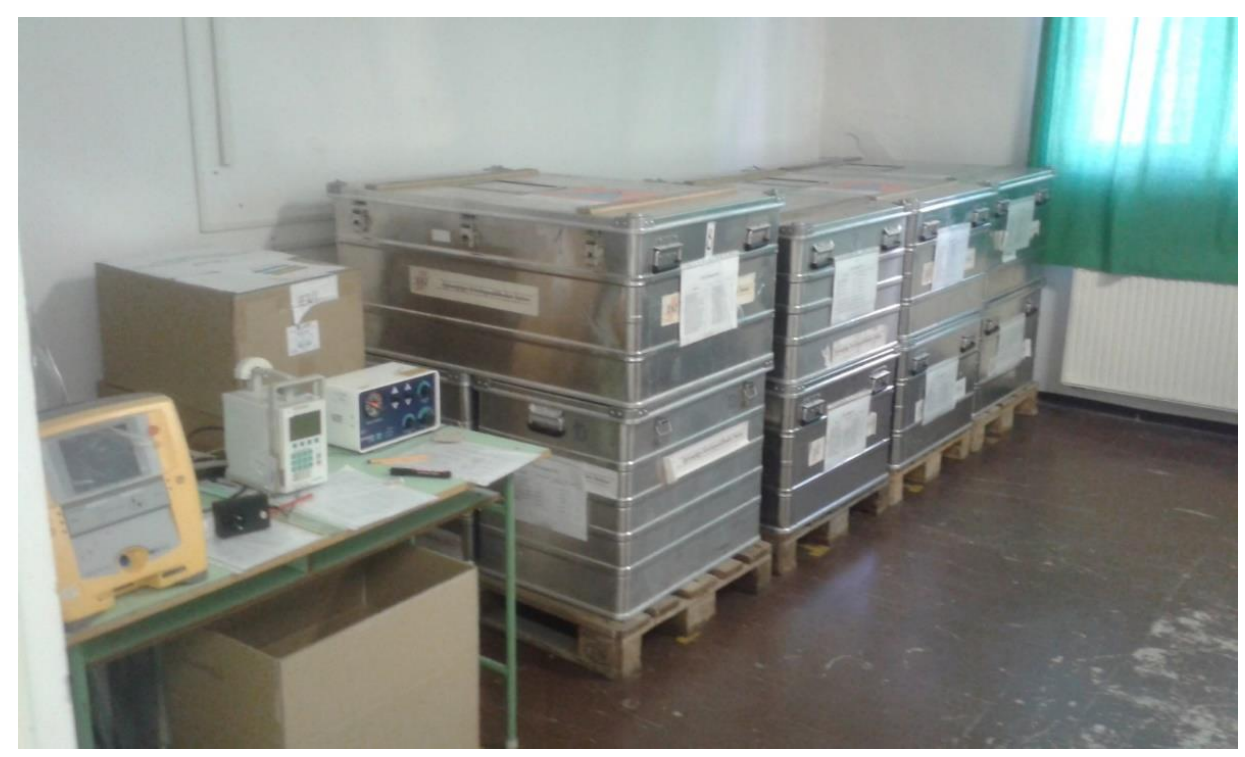

5. ábra Összekészített Gyorsreagálású Segélycsapat Felszerelés (GYSF)3 (Készítette a szerző, forrás: Állami Egészségügyi Ellátó központ Kappel Emília utcai raktár, 2018.11.07.)

\footnotetext{
${ }^{3}$ A képen a Gyorsreagálású Segélycsapat Felszerelés (GYSF) kiadásra előkészítve látható az Állami Egészségügyi Ellátó Központ Kappel Emília utcai Állami Egészségügyi Tartalék raktárában.
} 


\section{Járványügyi, Toxikológiai, Égési, Radiológiai modulok (JM, TM, ÉM, RM):}

Fertőző és toxikológiai megbetegedés, illetve az égési- és sugársérülés típusok tömeges bekövetkezésével járó egészségügyi válsághelyzetek esetére tartalmaz olyan - többnyire a szükség-gyógyintézetek normáiban is megtalálható - készleteket, amelyekre az adott esemény egészségügyi felszámolása során a fertőző, mérgezett betegek, illetve az égési- és sugársérültek ellátásához az átlagosnál nagyobb mennyiségben lehet szükség. [4;5]

\section{Egészségügyi Ellenőrző Állomás (EÁM), Mobil Járványügyi Zárlat modul (MJZ), Egészségügyi Szüröállomás (EMSZ), Rendvédelmi csapat-egészségügyi készlet (RCSK)}

A fenti csoportot alkotó egységek, önálló normaelemeket nem alkotnak, felszerelésük az adott egészségügyi válsághelyzet jellege alapján, a szükségletek figyelembevételével kerül meghatározásra a válsághelyzet bekövetkezését követően. [5]

\section{AZ ÁLLAMI EGÉSZSÉGÜGYI TARTALÉK A VÉDELMI CÉLÚ TARTALÉKOLÁS RENDSZERÉBEN}

A hidegháború után egy új biztonságpolitikai koncepció körvonalazódása figyelhető meg, mely a figyelmet a katonai fenyegetettségről és biztonságról egyre inkább a nem katonai természetü biztonsági tényezőkre fordítja. Ezek leginkább az energia-, környezeti-, pénz-, migrációs eredetü-, és kiberbiztonság területeken jelentkeznek.

A NATO tagság a magyar biztonság- és védelempolitikát komoly változtatásokra kényszerítette. A biztonsággal kapcsolatos kérdéseket már nem csak nemzeti, hanem nemzetközi és globális szinteken is szükséges kezelni. [6]

A nemzetgazdaság védelmi felkészítése és mozgósítása feladatai végrehajtásának szabályozásáról szóló 131/2003. (VIII.22.) Korm. rendelet definiálja a gazdaságmozgósítási igények azonnali és biztonságosabb kielégítése érdekében fenntartandó védelmi célú tartalékokat. [7]

A rendeltetésük szerint a védelmi célú tartalékok az alábbiak:

- Állami Céltartalék, melyet az érintett miniszterek gazdaságfelkészítési és mozgósítási feladataiban meghatározott fontosabb tevékenységek végrehajtásához szükséges anyagok és eszközök alkotnak (pl. árvízi védekezés elleni tartalék).

- Az Állami Egészségügyi Tartalék, melyet a külön jogszabályban meghatározott rendeltetésü orvostechnikai eszközök, gyógyszerek, különböző egészségügyi fogyóanyagok, valamint a szükséggyógyintézetek müködtetéséhez szükséges felszerelések alkotnak.

- Pénztartalékkészlet, azaz az ország pénzforgalmának mindenkori zavartalan biztosításához szükséges bankjegytartalék.

Az állam tulajdonosi jogait az Állami Egészségügyi Tartalék tekintetében az egészségügyért felelős miniszter, a Pénztartalékkészlet tekintetében a Magyar Nemzeti Bank elnöke, míg az Állami Céltartalék tekintetében az a miniszter gyakorolja, akinek védelmi felkészüléssel összefüggő feladatai végrehajtásának biztonságát szolgálja.

A Pénztartalékkészletet kivéve, melynek nagyságát a Magyar Nemzeti Bank elnöke állapítja meg, az egyes tartalékok kapacitástartalmát és összes vagyonértékét a Kormány határozza meg.

A nemzetgazdaság védelmi felkészülés nem csak a különleges jogrendi, hanem a különböző válsághelyzetek - az Állami Egészségügyi Tartalék esetében az egészségügyi válsághelyzetek - esetén felmerülö többletkapacitások biztosítását is jelenti. [7]

A közelmúltban a GYSF 2004-es indiai-óceáni cunami, a 2010-es haiti földrengés, és a 2013-as Fülöp-szigeteki tájfun kapcsán, a magyarországi segítségnyújtás részeként került bevetésre. 
Ebből következően a tartalékolásnak a békeidőszaki és felkészülést elősegítő tervezésre kell irányulnia, melyeket a beruházás, készletezés, kapacitás-fenntartás, adatgyüjtés, adatszolgáltatás mozzanatai jellemeznek leginkább. [8]

Az Állami Egészségügyi Tartalékolás rendszerében ez a koncepció még nem tudott teljes mértékben megvalósulni, az elmozdulást nehezíti a készletezés diszlokációja és a készletek korszerütlensége.

\section{AZ ÁLLAMI EGÉSZSÉGÜGYI TARTALÉK SZEREPE A KATONAI-, KATASZTRÓFAVÉDELMI- ÉS CIVIL EGYÜTTMÜKÖDÉSBEN}

\section{A 21. századi védelmi rendszerben kiemelt szerepet kap a biztonság fogalma.}

A biztonság a veszély fogalmával együtt kap értelmet, azt jelenti, hogy el tudjuk hárítani, fel tudjuk számolni a veszélyhelyzeteket.

Magyarország Nemzeti Biztonsági Stratégiája a biztonság fogalmát a válsághelyzet típusoktól függetlenül, átfogóan közelíti meg, kiemeli, hogy a biztonsági kérdések kezeléshez átfogó kormányzati eszközök szükségesek. A biztonsági környezetben, több síkon jelentkező fenyegetettségek érintik a kormányzati és nem kormányzati szervezeteket egyaránt. [9]

„Az átfogó megközelítés az összes szükséges nemzeti, illetve nemzetközi polgári és katonai elem - beleértve a politikai, diplomáciai, gazdasági, pénzügyi, információs, szociális, gazdasági, kereskedelmi, katonai stb. képességeket - együttes, koordinált alkalmazását jelenti a konfliktus megoldása érdekében." [10]

A védelem biztosítása, a védekezés egységes irányítása állami feladat. A katasztrófavédelemről, és a hozzá kapcsolódó egyes törvények módosításáról szóló 2011. évi CXXVIII. törvény kimondja, hogy a katasztrófavédelem nemzeti ügy, és minden állampolgárnak joga és kötelessége részt venni a katasztrófák elleni védekezésben.

„A biztonságot fenyegető támadások kivédésében, elhárításában hatékonynak bizonyult módszerekből, a tapasztalatok alapján megfogalmazható válságkezelési alapelvek alapján úgy tünik, hogy a válságok kezelésének hatékony felfogása egyre inkább katasztrófavédelmi megközelítésü kell, legyen.” [11]

Ezért a napjainkban müködő komplex, egységes katasztrófavédelmi rendszernek tudni kell kapcsolódni a védekezésben részt vevő egyéb állami és civil szervezetekkel.

„A központi államigazgatási szervek szintjén, katasztrófahelyzetekben a belügyminiszter vezetésével müködő Katasztrófavédelmi Koordinációs Tárcaközi Bizottságban (KKB) biztosított a honvédelmi és egészségügyi tárca kijelölt állami vezetőinek együttmüködése a katasztrófahelyzet egészségügyi felszámolásával kapcsolatos kormányzati döntéseinek előkészítésében, a védelmi bizottságok, valamint a védekezésben részt vevő szervek tevékenységének összehangolásában.” [10]

Válsághelyzetek, veszélyhelyzetek kialakulása esetén szinte minden esetben készülni kell az eseményt elszenvedők sérüléseinek ellátására, az életek mentésére. A kialakult helyzetek felszámolása nem oldható meg az egészségügyi ellátó rendszerben rendelkezésre álló kapacitásokkal, ezért előbb-utóbb sor kerülhet az Állami Egészségügyi Tartalék bevetésére.

Békeidőben az együttmüködés leginkább a rendezvények közös biztosítása, az éves rendszerességgel megrendezett Mobil Orvosi Segélyhely (MOSH) telepítő, komplex katonaicivil gyakorlatok, illetve a Katasztrófavédelmi Koordinációs Tárcaközi Bizottság által megrendezett Országos Nukleáris Baleset Elhárítási Rendszer (ONER) gyakorlatok során mutatkozik meg. Az ONER gyakorlatok során az Állami Egészségügyi Tartalék részeként lehívható Radiológiai Modul kap nagyobb szerepet. 


\section{KÖVETKEZTETÉSEK}

Fontosnak tartom hangsúlyozni, hogy az Állami Egészségügyi Tartalék nélkülözhetetlen eleme a védelmi célú tartalékolásnak, illetve alapját képezi a válsághelyzetek felszámolása során szükséges katonai-, katasztrófavédelmi- és civil együttmüködésnek.

A nemzetgazdasági és biztonsági kérdésekben általában a nemzeti mellett a nemzetközi és a globális szintü megközelítés a mérvadó, mégis az Állami Egészségügyi Tartalék készletezésével kapcsolatos kérdések alig szakadtak el a hidegháborús doktrínáktól. A raktárak, készletek diszlokációja, még a tömegpusztító fegyveres konfliktusok kezelését szolgáló koncepciót követi.

$\mathrm{Az}$ Állami Egészségügyi Tartalék jelenlegi helyzetét tekintve elmondható, hogy a raktárhálózat feltérképezésével, felmérésével, a készletek tételes áttekintésével egy átfogó racionalizálási javaslat elkészítésére és elfogadására van szükség. Az erre vonatkozó minden releváns adat átfogó, digitalizált rendszerbe szedésével, a jogosultsági és hozzáférési szintek világos rendezésével megoldható a párhuzamosságok felszámolása, a védelmi- és a civil szektor feladat-megosztásának tisztázása, a kutatás-fejlesztés irányainak kijelölése.

\section{FELHASZNÁLT IRODALOM}

[1.] 1997. évi CLIV. törvény az egészségügyröl; https://net.jogtar.hu/jogszabaly?docid=99700154.TV

[2.] 521/2013. (XII. 30.) Korm. rendelet az egészségügyi válsághelyzeti ellátásról; https://net.jogtar.hu/jogszabaly?docid=A1300521.KOR

[3.] 1/2016. (I. 13.) EMMI rendelet az Állami Egészségügyi Tartalékkal való gazdálkodás szabályairól; https://net.jogtar.hu/jogszabaly?docid=A1600001.EMM

[4.] Tervezési Útmutató a megyei tisztifőorvosok részére; EMMI, 15594/2013/EGP iktatószám

[5.] Az Állami Egészségügyi Tartalékkal való gazdálkodás szabályairól szóló új rendelet kapcsán kért Iránymutatás; EMMI 6551/2016/EGP iktatószám

[6.] A védelemgazdaság helyzete Magyarországon; http://epa.oszk.hu/02700/02735/00080/pdf/epa02735_katonai_logisztika_2015_2_005052.pdf (letöltve: 2019.03.09.)

[7.] 131/2003. (VIII. 22.) Korm. rendelet a nemzetgazdaság védelmi felkészítése és mozgósítása feladatai végrehajtásának szabályozásáról; https://net.jogtar.hu/jogszabaly?docid=A0300131.KOR

[8.] A védelemgazdaság biztonságpolitikai összefüggései napjainkban; Hadmérnök, XII. Évfolyam 3. (2018) 339-352. o. http://www.hadmernok.hu/183_25_babos.pdf (letöltve: 2019.03.09.)

[9.] 1035/2012. (II.21.) Korm. határozat Magyarország Nemzeti Biztonsági Stratégiájáról; http://2010-2014.kormany.hu/download/f/49/70000/1035_2012_korm_hatarozat.pdf

[10.] Szerk: KESZELY L.: Az Átfogó megközelítés és a védelmi igazgatás. Zrínyi Kiadó, Budapest, 2013. 207 o.

[11.] http://hmvedelmiigazgatas.kormany.hu/download/2/f6/31000/04_2013_Az_atfogo_meg kozelites_es_vedelmi_igazgatas.pdf (letöltve: 2018.10.24.) 
[12.] ÜRMÖSI K.: A biztonság dimenziói, biztonsági stratégia napjainkban, hazánkban; Hadtudományi Szemle, 5. évfolyam 1-2. (2012) 172-184. o.

[13.] http://epa.oszk.hu/02400/02463/00012/pdf/EPA02463_hadtudomanyi_szemle_2012_12_172-184.pdf (letöltve: 2019.03.09) 